\title{
Mechanical Behavior of Glass/Porous Alumina by Contact Loading
}

\author{
Chul Kim, Sang Kyum Kim, Tae Woo Kim, and Kee Sung Lee ${ }^{\dagger}$
}

School of Mechanical Systems Engineering, Kookmin University, Seoul 136-702, Korea

(Received July 28, 2014; Revised August 29, 2014; Accepted September 1, 2014)

\section{유리/다공성 알루미나의 접촉하중에 의한 기계적 거동

\author{
김 철 · 김상겸 $\cdot$ 김태우 · 이기성 \\ 국민대학교 기계시스템공학부 기계설계전공
} \\ (2014년 7월 28일 접수 ; 2014년 8월 29일 수정 ; 2014년 9월 1일 채택)}

\begin{abstract}
Porous alumina with different porosities, 5.2 - 47.5\%, were coated with cover-glass having a thickness of $160 \mu \mathrm{m}$, using epoxy adhesive. We investigated the effect of the porosity of the substrate layer on the crack initiation load, and the size of cracks propagated in the coating layer. Hertzian indentations were used to evaluate the damage behavior under a constrained loading condition. Typically, two types of cracks, ring cracks and radial cracks, were observed on the surface of the glass/porous alumina structure. Indentation stress-strain curves, crack initiation loads, crack propagation sizes, and flexural strengths were investigated as a function of porosities. The results indicated that a porosity of less than $30 \%$ and a higher substrate elastic modulus were beneficial at suppressing cracks occurrence and propagation. We expect lightweight mechanical components with high strength can be successfully fabricated by coating and controlling porosities in the substrate layer.
\end{abstract}

Key words : Porous alumina, Contact loading, Hertzian indentation, Mechanical behavior

\section{1. 서 론}

세라믹스의 표면에 일정한 두께로 코팅을 하는 기술은 세라믹스의 표면이 받는 영향을 감소시키기 위한 목적으 로 모재를 보호하고자 하는 기능도 있으나, 코팅을 통해 서 부품 전체의 특성을 향상시킬 목적으로도 활용된다. 코팅에 의해 향상될 수 있는 성능은 표면성능, 전자기적 특성, 광학적 성능, 열적 특성, 물리적 성능, 화학적 성능, 생물화학적 특성과 장식적 특성 등 다양한 공학 분야에 서의 발전을 이끌어왔다. ${ }^{1,2}$ 또한 외부의 하중에 견디고, 변형 및 파손에 저항이 요구되는 경우, 내마모성과 저 마 찰계수가 요구되는 경우 등 기계적 특성을 향상시킬 목 적으로의 코팅기술 역시 많은 연구가 이루어지고 있다.-4) 파손을 방지하기 위한 도자기, 식기에 도입되는 유약뿐만 아니라 자동차 라미네이트(laminate) 유리, ${ }^{5,6)}$ 절삭공구, 베 어링 등의 기계구조용 부품, 치아, 인공 뼈 등에 적용되 는 바이오 코팅재 ${ }^{7,8)}$ 필터 및 분리막 제품의 비대칭 구조

${ }^{\dagger}$ Corresponding author : Kee Sung Lee

E-mail : keeslee@kookmin.ac.kr

Tel : +82-2-910-4834 Fax : +82-2-910-4839
체, ${ }^{9,10)}$ 가스터빈 부품을 보호하기 위한 코팅재 ${ }^{11-13)}$ 등 다 양한 적용도 이루어지고 있다.

모재 위에 코팅층을 도입하는 층상재료에 있어서 코팅 재의 선택과 설계는 매우 중요하다. 이는 잘못된 설계로 인하여 다양한 목적으로 도입된 코팅층이 오히려 빠르게 변형되거나 파손될 수 있기 때문이다. 자동차 부품 등 많 은 기계부품들은 부품들이 서로 연결되고 조립되어 상호 맞물려 작동하는 경우가 많다. 따라서 구속된 상태 (constrained condition)에서 작동 시 받는 하중 하에서의 코팅재의 선택은 매우 중요하다. 특히 구속 상태에서 세 라믹스 부품소재의 변형률이 일정하다고 본다면 재료의 탄성계수가 곧 응력(stress)에 비례하고, 탄성계수는 재료 에 의해 결정되는 상수이다. 코팅재는 일반적으로 모재와 는 다른 소재가 코팅되므로, 서로 다른 소재의 탄성계수 불일치(elastic modulus mismatch)는 코팅층의 파손과 수명 에 영향을 주는 중요한 변수이다. ${ }^{14)}$ 만약 구속된 하중을 받는 상태에서 열이 가해지는 환경이라면 서로 다른 소 재의 열팽창 특성은 열팽창계수의 불일치(thermal expansion mismatch)를 야기하므로 이에 의한 응력 차와 파손 역시 고려하여 설계되어야 한다. ${ }^{15)}$ 또한 코팅공정 시 모 재와 코팅층간의 두께(coating thickness)는 주요한 기하학 
적 인자(geometrical factor)로 고려되며, 코팅층-모재층간의 계면강도(interfacial strength), 코팅-모재층의 경도(hardness)와 인성(toughness) 역시 고려해야 할 주요한 설계 변수이다. ${ }^{16)}$

내하중, 내열, 내마모성 등을 고려한 비대칭성 코팅구 조체(asymmetric structure)에 있어서 상기와 같은 설계변 수에 의한 연구는 많이 이루어졌으나, 구속된 하중 하에 서 모재층의 영향에 대해서는 많은 연구가 이루어지지 않 고 있다. 특히 세라믹스 모재층의 기공율(porosity)에 의한 영향에 대해서는 정량적인 연구와 고찰이 이루어지지 않 고 있다. 기공(pore)은 세라믹스의 강도를 낮추는 결함으 로도 작용하지만 잘 제어할 경우 제품의 무게를 가볍게 하면서도 동시에 강도를 유지하거나 향상시킬 수 있다. 기계구조용 부품은 에너지 효율적인 측면을 고려할 때 가 벼운 부품소재가 유리하므로 다공성의 소재가 고려된다. 동시에 기계적 강도 등이 저하되지 않아야 하므로 기공 율(porosity)과 코팅을 주요한 설계변수 중 하나로 고려하 는 것이 중요하다. ${ }^{17,18)}$

따라서 본 연구에서는 유리/다공성 알루미나의 소재를 모델 재료로 제작하여 평가하는 연구를 수행하였으며, 이 때 특히 모재인 알루미나 소재의 기공율(porosity)을 다양 하게 변화시켰다. 유리는 취성이 있고 균일한 재질, 또한 접촉하중 시 모재의 영향을 충분히 받도록 하기 위해, 얇 은 커버글라스(cover glass)를 사용하였다. 구속된 상태에 서 적용되는 하중은 구형의 초경구를 압흔하는 헤르찌안 압흔실험(Hertzian indentation) ${ }^{19)}$ 을 이용하였다. 이 압흔실 험은 시험편 전체를 파괴시켜 평가하지 않고 시험편의 일 부분을 국소파괴(local fracture)함으로써, 한 시편 내에서 도 위치를 이동하며 많은 결과 값을 얻고 통계처리 등도 쉽게 얻을 수 있는 장점이 있다. 본 연구에서는 이 평가 방법을 이용하여 소재별로 균열의 개시하중과 전파된 크 기를 측정하는 연구를 수행하였다.

\section{2. 실험 방법}

코팅재로서는 균일한 두께 $(d=160 \mu \mathrm{m})$ 를 갖는 현미경 관찰용 상용 커버글라스(cover glass, Marienfeld, Germany)를 사용하였다. 다공층 알루미나는 다양한 메이커의 알루미 나를 사용하였으며(AKP-50, AES-11, ALCOA, Japan), 알 루미나의 기공율을 제어하기 위하여 출발입도가 서도 다 른 분말들 $(0.4,1.2,5.5,9.8 \mu \mathrm{m})$ 을 사용하였다.

코팅재로 사용한 유리의 상, 하면에 균일한 결함(flaws) 들을 도입하기 위하여 $\mathrm{SiC}$ 연마입자가 포함된 $(\mathrm{SiC} 600$ grit) 슬러리를 사용하여 $1 \sim 2$ 분간 연마를 하였다. ${ }^{20)}$ 광학 현미경을 사용하여 결함을 관찰하면서 연마 시간을 조절 하였다. 알루미나 분말들은 $40 \times 40 \mathrm{~mm}$ 의 사각 몰드에 넣 고 $50 \mathrm{MPa}$ 의 압력으로 성형하였다. 얻어진 성형체는 소
결로에 넣고 $1100 \sim 1600^{\circ} \mathrm{C}$ 에서 서로 다른 기공율의 알루 미나 소결체를 제조하였다. 제조한 소결체는 다이아몬드 휠(wheel)로 가공하여 $4.5 \times 6 \times 36 \mathrm{~mm}$ 의 크기로 제작한 후, 다이아몬드 그라인더(grinder)와 페이스트(paste, $6,3,1 \mu \mathrm{m}$ ) 를 사용하여 표면을 경면연마(polishing)해 주었다.

연마처리가 끝난 다공성 알루미나는 폴리머 접착제 (epoxy, Harcos Chemicals, Hellesville, NJ, USA)를 이용 하여 커버글라스와 접착하였다. 접착제를 한두 방울 유리 에 떨어뜨린 후 면봉을 이용하여 균일한 두께가 되도록 퍼뜨린 후 다공성 알루미나를 얹고 바이스에 물려 가압 한 상태에서 12 시간 이상을 유지하였다. 접착된 단면을 다이아몬드 그라인더와 페이스트를 사용하여 연마한 후 광학현미경으로 두께를 확인하여, $10 \mu \mathrm{m}$ 이상이 되는 구 조체는 시험에서 제외하였다. ${ }^{19)}$

알루미나 모재의 기공율은 아르키메데스의 원리를 이 용하여 측정하였다. 계산한 식은 식 (1)과 같으며, 식에서 $\mathrm{w}_{\mathrm{dry}}$ 는 건조무게, $\mathrm{w}_{\mathrm{sus}}$ 은 현수무게, $\mathrm{w}_{\mathrm{sat}}$ 는 포수무게이다.

$$
\text { porosity }=\left[\left(\mathrm{w}_{\text {sat }}-\mathrm{w}_{\text {dry }}\right) /\left(\mathrm{w}_{\text {sat }}-\mathrm{w}_{\text {sus }}\right)\right] \times 100 \%
$$

코팅층과 모재층의 탄성계수는 음향 펄스를 가하여(acoustic impulse excitation apparatus, Tektronics, 5800PR, USA) 구 하였으며 시험편 제작과 시험방법은 ASTM E1876-1을 따 라 진행하였다.

유리/다공성 알루미나 구조체에 초경 구를 압흔하는 헤 르찌안 압입시험(Hertzian indentation) 방법으로 구속 상태 하에서의 접촉하중(contact loading)을 인가하였다. 손상관 찰을 명확히 하기 위하여 유리 코팅층 표면을 $15 \mathrm{~mA}$ 의 조 건으로 10 분간 금으로 코팅하였다. 압입은 만능시험기 (Instron 5567, USA)에서 일정한 하중을 가하여 시험하였 다. 구형압자는 반경 $r=3.18 \mathrm{~mm}$ 의 초경 구(WC : Tungsten Carbide, J \& L Industrial Supply Co., Livonia, MI, $\mathrm{USA}$ )를 사용하였으며, 압입하중 $P$ 는 초기에 $5 \mathrm{~N}$ 부터 하 중간격을 $5 \mathrm{~N}$ 씩 증가시키다가 $50 \mathrm{~N}$ 부터는 $10 \mathrm{~N}, 100 \mathrm{~N}$ 부터는 $25 \mathrm{~N}, 300 \mathrm{~N}$ 부터는 $50 \mathrm{~N}, 500 \mathrm{~N}$ 부터는 시편이 파괴될 때까지 $250 \mathrm{~N}$ 의 간격으로 각각 증가시켜 서로 다 른 하중으로 증착층의 표면에 구형압자를 압입하였다. 이 때, 손상영역의 직경을 예측, 고려하여 하중을 가하는 위 치를 압입하중에 따라 최소 $0.5 \mathrm{~mm}$ 에서 $5 \mathrm{~mm}$ 의 간격을 두어 손상 간에 상호 영향이 없도록 정밀히 제어하였으 며, 압입을 가하는 속도는 $0.2 \mathrm{~mm} / \mathrm{min}$ 가 되도록 시험기의 cross-head를 조정하였다. 압입 후 광학현미경을 이용하여 손상영역을 관찰하여 시편 표면에 형성된 손상영역의 직 경 $2 a$ 를 측정하여 압흔응력-변형률 곡선을 구하였다. ${ }^{19)}$ 손 상영역의 직경은 가로와 세로의 길이를 측정하여 평균을 구하였다. 압흔응력(indentation stress, $\mathrm{GPa}$ )과 압흔변형률 (indentation strain)은 다음 식 (2)와 (3)에 의해 구하였다. 
Indentation stress, $p_{\mathrm{o}}=P / \pi a^{2}$

Indentation strain, $a / r$

접촉하중 하에서 유리의 표면에 발생하는 원형균열과 방사성 균열의 임계하중과 균열의 크기를 측정하기 위해 앞에서와 같은 조건으로 금 코팅을 한 후 만능시험기 (Instron 5567, USA)을 이용하여 유리/다공성 알루미나의 표면에 $P=150,250,350 \mathrm{~N}$ 등 반경 $r=3.18 \mathrm{~mm}$ 의 초경 구를 사용하였다. 이 때 가한 하중 속도는 $0.09 \mathrm{~mm} / \mathrm{min}$ 가 되도록 하였다. 다양한 접촉하중 하에서 코팅층의 표 면에서 발생하는 균열은 광학현미경(optical microscope, NIKON, Japan)을 이용하여 관찰해 균열의 개시하중 (initiation load)을 판단하였으며, 균열의 크기는 이미지 분 석을 통해 면밀히 측정하였다.

코팅구조체의 강도를 측정하기 위해 3점 굽힘실험법(3point flexural test)을 이용하였다. 코팅한 유리/다공성 알 루미나와 다공성 알루미나 시험편들을 만능시험기를 이 용하여 굽힘 실험을 하였다. 강도실험을 위해 시험편의 크기는 $4.5 \times 6 \times 36 \mathrm{~mm}$ 로 제작하였으며, 코팅구조체의 표 면을 $1 \mu \mathrm{m}$ 까지 경면 연마(polishing)한 후, 다이아몬드 그 라인더(grinder)를 이용하여 모따기(chamfering)를 해 주었 다. 최대 인장응력이 코팅층에 작용되도록 시험편을 배치 시킨 후 굽힘 실험을 하였다. 이 때 하부 스팬(span)은 $20.15 \mathrm{~mm}$ 로 선정하였으며 하중 속도는 $0.2 \mathrm{~mm} / \mathrm{min}$ 이 되 도록 하였다. 시험편이 파괴될 때까지의 하중을 가하여 이 때 얻은 하중을 이용하여 굽힘 강도 값을 계산하였다.

\section{3. 결과 및 고찰}

서로 다른 크기의 분말과 $(0.4,1.2,5.5,9.8 \mu \mathrm{m})$ 서로 다 른 소결온도에서 $\left(1100,1200,1300,1400^{\circ} \mathrm{C}\right)$ 서로 다른 기 공율을 갖는 다공성 알루미나를 제작하였으며, 이 때 기 공율은 $5.2 \sim 47.5 \%$ 의 범위 내에서 제조할 수 있었다. 서 로 다른 기공율을 갖는 알루미나의 표면에 초경 구로 압 흔 하여 압흔 응력과 압흔 변형률을 측정하여 도시한 결 과를 Fig. 1에 나타내었다. 그래프에서와 같이 동일한 소 재의 알루미나임에도 불구하고 압흔거동은 기공율에 의 해 크게 영향을 받는 것으로 나타났다. 기공율 $5.2 \%$ 의 모 재 위에 코팅된 유리의 경우 탄성계수(초기하중-변형율의 선형부분의 기울기에 해당)가 상대적으로 가장 높았으며, 기공율 $41.2 \%$ 이상에서는 하중을 받자마자 항복(yield)이 일어나 소성적인 거동을 보였다. 기공율이 $17.7,25.7$, $34.3 \%$ 의 경우는 어느 정도 탄성거동을 나타내다가 일정 하중 하에서 국부적인 변형이 일어나 중간 정도의 거동 을 나타내었다. 따라서 일정한 구속하중 하에서 서로 다 른 기계적 거동을 나타내는 다공성 알루미나들을 그 기 공율을 제어함으로써 제조할 수 있었다.

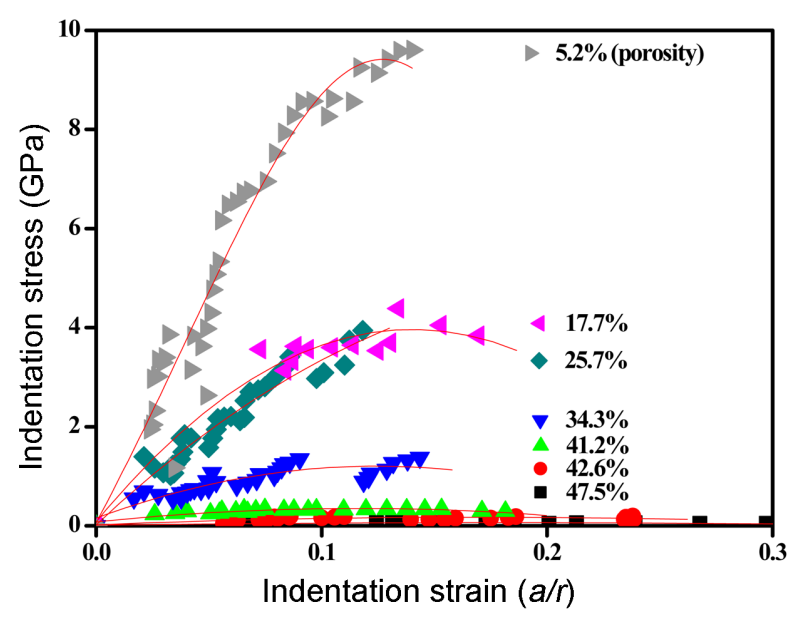

Fig. 1. Indentation stress-strain curves for porous $\mathrm{Al}_{2} \mathrm{O}_{3}$.

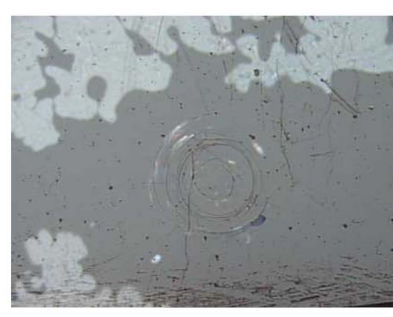

(a)

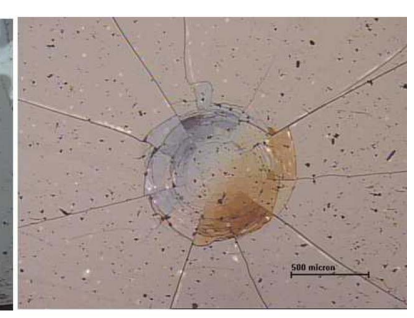

(b)
Fig. 2. Representative fracture patterns in the glass on the porous $\mathrm{Al}_{2} \mathrm{O}_{3}$ substrate, (a) typical ring (cone) cracks and (b) typical radial cracks. The contact damages from WC sphere radius $r=3.18 \mathrm{~mm}$ at load of $250 \mathrm{~N}$ and the porosity in the substrate is $34.3 \%$ (a) and $42.6 \%(b)$, respectively. The length of scale bar is $500 \mu \mathrm{m}$.

다공성 알루미나 모재 위에 현미경용 커버글라스를 에 폭시 수지로 일정두께로 접착시킨 후 유리표면에 초경 구 로 압흔하중을 가할 경우 형성되는 대표적인 균열의 종류 를 Fig. 2에 나타내었다. 사용한 초경 구의 반경은 $3.18 \mathrm{~mm}$ 이었고, (a)는 기공율 $34.3 \%$ 의 모재위에 코팅한 유리에서 $P=250 \mathrm{~N}$ 의 하중이 인가되었을 때 표면에 형성된 균열이 며, (b)는 기공율 $42.6 \%$ 의 모재위에 코팅한 유리표면에서 동일 하중이 인가되었을 때 형성된 균열이다. 그림에서와 같이 모재의 기공율에 관계없이 크게 두 가지 종류의 균 열이 나타났는데, 첫 번째는 (a)와 같은 접촉부위 바깥쪽 으로 형성되는 원형의 균열(ring crack)과, (b)와 같은 방 사성 방향으로 진전하는 방사형 균열(radial crack)이었다. 이 러한 두 가지 양상의 균열은 코팅층과 모재층 사이에 개재 된 접착층이 있는 층상재료에서 흔히 관찰되는 종류로서, ${ }^{20)}$ 원형균열은 표면에 수직한 균열이 형성되다가 $\sigma_{33}$ 의 방향 으로 원추형 모양의 균열(cone crack)로 진전되어 표면에 서 링 형태의 균열로 관찰되는 것이며, ${ }^{19)}$ 방사형 균열은 코팅층과 모재층 간 계면으로부터 코팅층에 작용하는 굽 


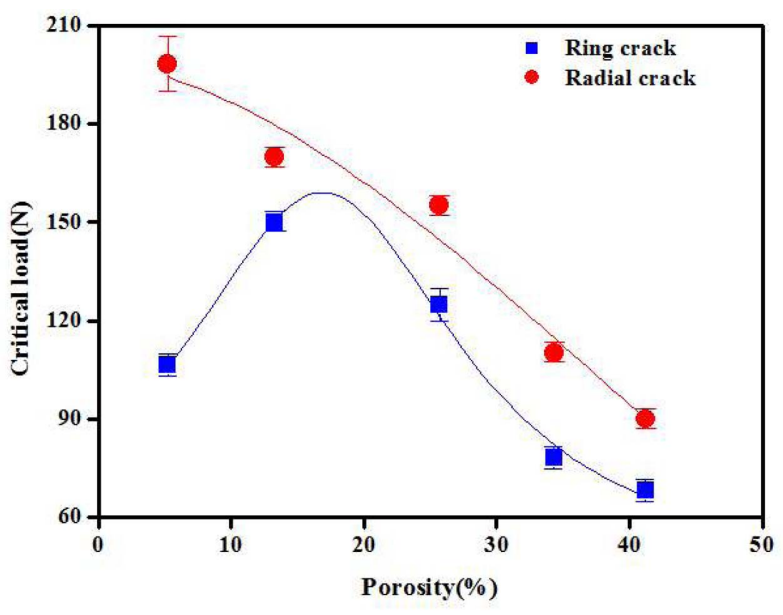

Fig. 3. Plot of measured critical loads of ring and radial crack as a function of porosity in the substrate of glass $/ \mathrm{Al}_{2} \mathrm{O}_{3}$ bilayer.

힘 응력(bending stress)에 의해 계면에 수직하게 발생하여 표면으로 진전되는 것이다. 그림에서와 같이 기공율의 차 이가 아주 크게 나지는 않음에도 불구하고 또 동일한 유 리가 $160 \mu \mathrm{m}$ 의 두께로 모재를 차단(blocking)하고 있음에 도 표면에 형성된 균열의 양상은 매우 다르게 나타내며, 이는 모재의 영향이 매우 중요함을 시사한다.

모재의 기공율을 $5.2,13.3,25.7,34.3,41.2 \%$ 로 제어한 다공성 알루미나 모재 위에 동일한 커버글라스를 코팅한 후 반경 $3.18 \mathrm{~mm}$ 의 초경 구로 압흔을 하였을 때, 균열이 처음 형성되는 임계하중, 즉 균열개시하중(crack initiation load)을 모재의 기공율의 함수로 Fig. 3에 도시하였다. Fig. 2에서와 같이 원형균열과 방사성 균열을 구분하여 각각의 개시하중을 관찰, 측정하여 도시하였다. 그래프에 도시한 바와 같이 기공율 범위 내에서는 기공률에 관계 없이 원형균열이 보다 낮은 하중하에서 발생하며, 방사성 균열의 발생 임계하중은 상대적으로 높은 것으로 분석되 었다. 또 모재의 기공률이 증가하게 되면 코팅층에 생기 는 방사성균열은 상대적으로 낮은 하중 하에서 발생하였 다. 이러한 이유는 다음 (4)식에서와 같이 방사성 균열의 임계하중 $\left(P_{\mathrm{rad}, \mathrm{critical}}\right)$ 은 모재의 강도 $\sigma_{\mathrm{F}}$ 와 코팅층 $(E \mathrm{c})$ 과 모 재층 $(E \mathrm{~s})$ 간의 탄성계수 차이 $(E \mathrm{c} / E \mathrm{~s})$ 에 의존하기 때문이다. ${ }^{20)}$

$$
P_{\text {rad, critical }}=B \sigma_{\mathrm{F}} d^{2} / \log (\mathrm{CEc} / E \mathrm{~s})
$$

위 (4)식에서 $d$ 는 코팅층의 두께를 의미하며, $\mathrm{B}$ 와 $\mathrm{C}$ 는 재료에 의해 결정되는 상수 값이다. Table 1 에는 기공율 이 다른 알루미나 모재의 탄성계수를 측정한 값을 나타 내었다. 코팅층의 탄성계수 값은 약 $70 \mathrm{GPa}$ 로 측정되었 으며, 알루미나 모재의 경우 기공율이 없는 경우는 370 $\mathrm{GPa}$ 의 높은 탄성계수를 나타내지만, $40 \%$ 이상 기공율이
Table 1. The Measured Porosity and the Estimated Elastic Modulus of the Glass and $\mathrm{Al}_{2} \mathrm{O}_{3}$

\begin{tabular}{ccc}
\hline Layer & $\begin{array}{c}\text { Apparent } \\
\text { Porosity }(\%)\end{array}$ & $\begin{array}{c}\text { Elastic } \\
\text { Modulus(GPa })\end{array}$ \\
\hline coating -glass & 0 & 70 \\
\hline & 0 & 370 \\
& 5.2 & 344.0 \\
$\mathrm{Al}_{2} \mathrm{O}_{3}$ & 13.3 & 289.7 \\
& 17.7 & 246.8 \\
& 25.7 & 159.8 \\
& 34.3 & 94.7 \\
& 41.2 & 48.6 \\
& 42.6 & 42.3 \\
& 47.5 & 25.7 \\
\hline
\end{tabular}

증가하게 되면 유리보다도 탄성계수가 저하하는 것을 알 수 있다. 따라서 식 (4)에 의해 $P_{\mathrm{rad}, \text { critical }}$ 이 기공율 감소에 따라 감소하게 되므로 Fig. 3의 거동을 이해할 수 있다.

반면 원형균열의 임계하중 $\left(P_{\text {cone, critical }}\right)$ 은 기공율이 낮은 경우 $13.3 \%$ 의 균열개시하중이 $5.2 \%$ 의 균열개시하중보다 높은 것으로 나타났다. 이는 원형균열의 임계하중은 다음 식 (5)와 같이 균열의 저항성(crack resistance, $G_{\mathrm{c}}$ )에 의존 하기 때문으로, ${ }^{20)}$ 기공율이 적은 범위 내에서는 기공이 파괴인성의 향상에 도움을 줄 수 있다. 이는 형상과 크 기가 제어된 기공이 포함되어 있는 경우, 균열에 대한 손상저항성(damage tolerance)을 향상시키는데 기여하기 때문이다. ${ }^{21,22)}$

$$
P_{\text {cone, critical }}=A r G_{\mathrm{c}}
$$

코팅/다공성 알루미나 구조체의 표면을 반경 $3.18 \mathrm{~mm}$ 의 초경 구로 접촉하중 $P=150,250,350 \mathrm{~N}$ 하에서 압흔 한 후 표면에 형성된 균열의 최종적인 크기를 측정하여 Fig. 4에 나타내었다. 전형적으로 발견되는 두 종류의 균 열, 즉 원형균열과 방사성 균열에 대해 각각 구분하여 그 크기를 나타내었으며, 기공율의 함수로 도시하였다. Fig. 4 에서와 같이 기공율 $30 \%$ 이하에서는 주로 원형균열이 형 성되었으며, $30 \%$ 이상에서 방사성 균열이 상대적으로 크 게 형성됨을 알 수 있으며, 기공율이 $40 \%$ 이상으로 증가 하게 되면 균열의 크기는 현격히 증가하게 되는데 특히 방사성 균열의 크기가 급격하게 증가함을 알 수 있다. 이 러한 균열의 크기는 하중의 크기의 함수이다. 특히 기공 율이 $13.3 \%$ 이하에서의 원형균열의 크기가 $5.2 \%$ 에서의 크기보다 감소함을 알 수 있는데, 이러한 이유는 Fig. 3 에서 살펴본 바와 같이 $13.3 \%$ 의 경우 상대적으로 높은 임계하중 하에서 균열이 개시되기 때문으로 생각된다. 이 러한 결과는 기공율을 적절히 제어할 경우, 상대적으로 무게가 감소하면서도 높은 기계적 강도를 갖는 구조체를 설계할 수 있음을 의미한다. 


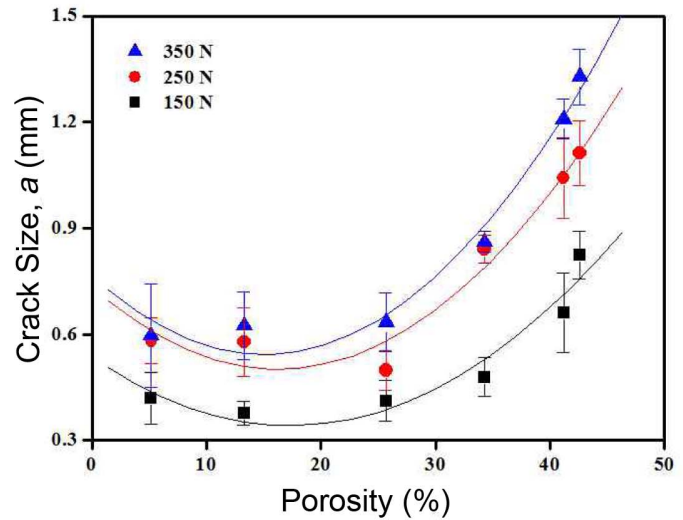

(a)

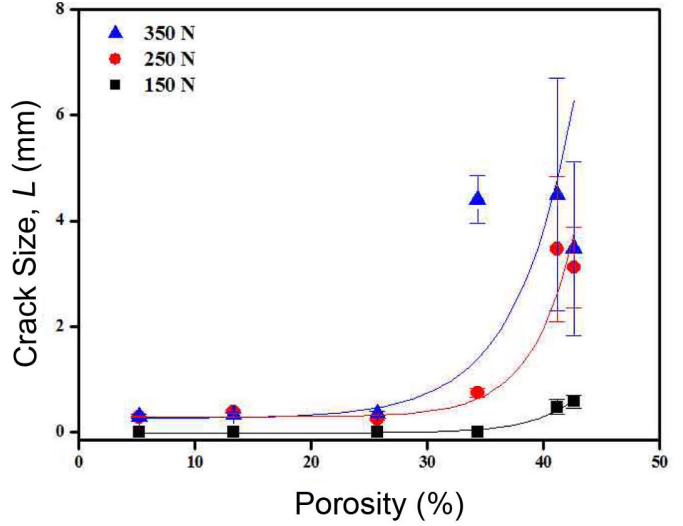

(b)

Fig. 4. Plot of cracks sizes as a function of porosity in the substrate of glass $/ \mathrm{Al}_{2} \mathrm{O}_{3}$ bilayer. The (a) ring crakcs and (b) radial cracks are produced under contact loadings of $\mathrm{WC}$ sphere radius $r=3.18 \mathrm{~mm}$ at load $P=150,250$, and $350 \mathrm{~N}$, respectively.

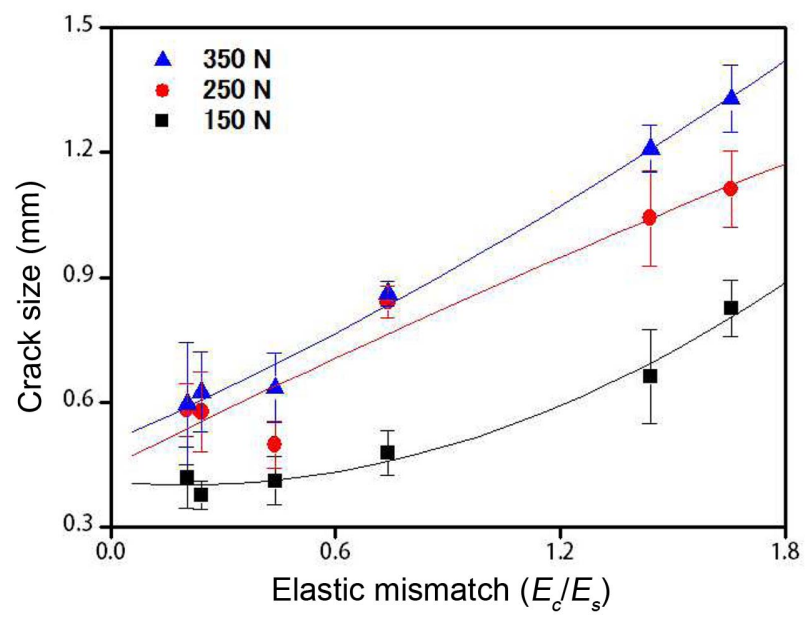

Fig. 5. Plot of cracks sizes for ring crack as a function of elastic mismatch for glass coatings on porous $\mathrm{Al}_{2} \mathrm{O}_{3}$. The cracks are produced under contact loadings of WC sphere radius $r=3.18 \mathrm{~mm}$ at load $P=150,250$, and $350 \mathrm{~N}$, respectively.

두 가지 균열 중에서 Fig. 2 와 같이 원형균열이 먼저 발 생하므로 원형균열의 크기를 측정한 후 이를 기공률이 아 닌 탄성계수 차이 $(E \mathrm{c} / E \mathrm{~s})$ 의 함수로 도시하여 Fig. 5에 나 타내었다. 서로 다른 하중, $P=150,250,350 \mathrm{~N}$ 하에서 측정된 균열을 동시에 나타내었다. 하중의 크기가 감소할 수록 형성되는 균열의 크기는 감소하였으며, 코팅층과 모 재층의 $E \mathrm{c} / E \mathrm{~s}$ 값이 감소할수록 형성되는 균열의 크기는 감 소하였다. 코팅층과 모재층이 각각 동일한 소재라면 $\mathrm{Ec} /$ $E \mathrm{~s}=1$ 이며, 1 보다 작아지거나 1 보다 커지게 되면 탄성계 수의 불일치(elastic mismatch) 정도는 증가한다. 구속조건 하에서 탄성계수의 불일치는 곧 응력불일치를 의미하고 $E_{\mathrm{c}} / E_{\mathrm{s}}=1$ 에서 벗어날수록 데이터 편차가 증가하는 경향 을 나타내었다. 반면 균열의 크기의 경우 1 을 기준으로 그 값이 감소하거나 증가함에 따라 균열의 크기가 증가

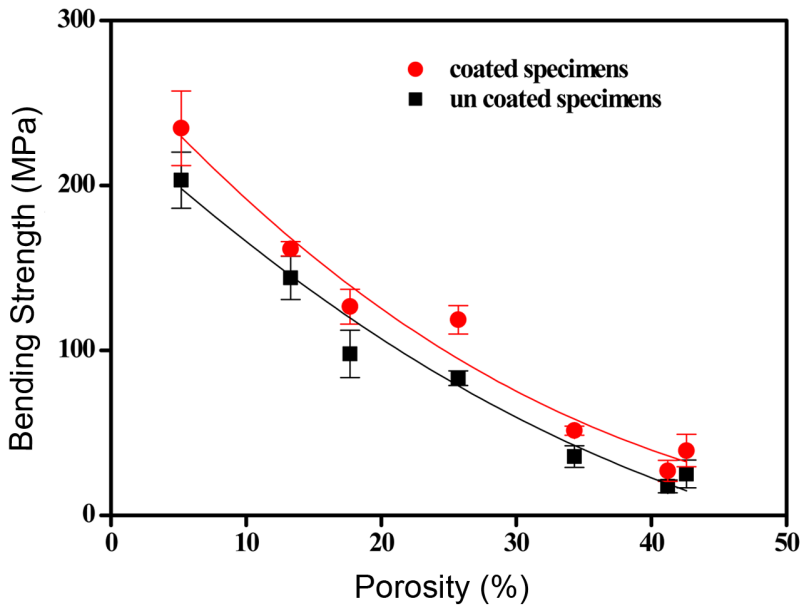

Fig. 6. The bending strength as a function of porosity in the substrate of glass $/ \mathrm{Al}_{2} \mathrm{O}_{3}$ bilayer. The strengths are measured for coated and uncoated specimens.

한 것이 아니라, 1 보다 증가할 경우는 증가하지만, 1 보다 작아질 경우는 오히려 균열의 크기가 감소하는 것을 알 수 있다. 이는 균열의 성장에 불일치가 영향을 주는 것이 아니라, 모재의 탄성계수 값이 영향을 주는 것을 의미한 다. 즉 코팅층보다 모재층의 탄성계수가 증가할수록(탄성 계수 불일치 $E \mathrm{c} / E \mathrm{~s}$ 값이 감소할수록) 균열의 성장을 억제 한다는 것을 나타낸다. 이러한 결과는 코팅/모재층의 층 상재료(비대칭 구조체)에서 코팅층에 형성된 균열의 성장 을 억제하기 위해서는 탄성계수가 높은 모재층을 사용하 면 유리하다는 결과를 제시한다.

Fig. 6 에는 유리/다공성 알루미나 구조체의 3점 굽힘 강 도를 기공율의 함수로 나타내었다. 굽힘 시험을 할 경우 하부스팬 사이의 면적에 최대 인장응력이 걸리게 되고, 취성이 있는 세라믹스의 경우는 이 면적 내 한 결함에서 최대 임계응력이 집중되면 균열이 개시되며 방사형 형태 


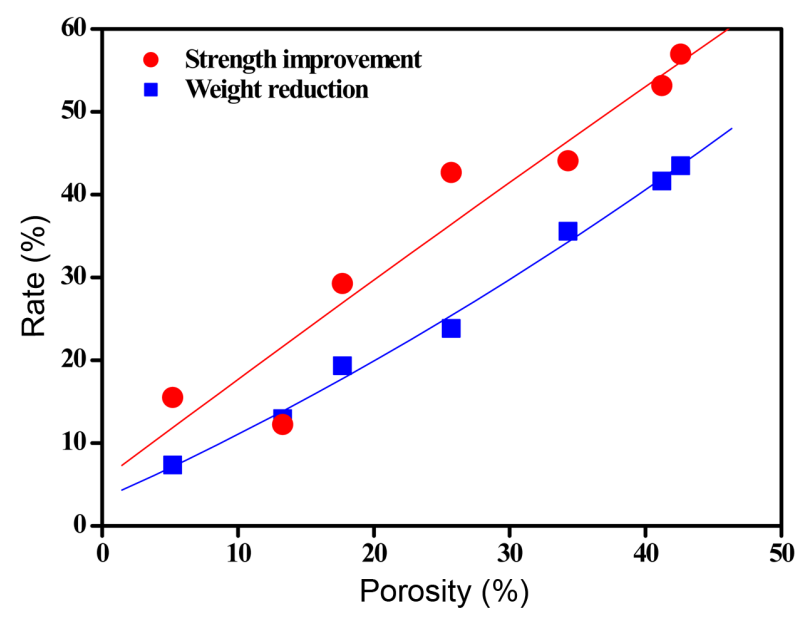

Fig. 7. The ratio of weight reduction and strength improvement plotted as a function of porosity in the substrate of glass $/ \mathrm{Al}_{2} \mathrm{O}_{3}$ bilayer.

의 균열로 성장하게 된다. 균열의 성장은 급작파괴 (catastrophic failure)의 양상으로 전파되어 파괴가 일어난 다. 따라서 Fig. 6의 강도 값의 결과는 Fig. 3에서 관찰한 방사성균열의 균열개시하중과 유사한 경향을 나타내었다. 즉 방사성균열이 상대적으로 낮은 하중에서 개시되면 동 일조건까지 성장된 균열에 의해 응력이 집중, 급작파괴로 파손이 일어나게 되므로 강도가 감소하게 된다. Fig. 6에 코팅을 하지 않은 다공성 알루미나 구조체에 대해서도 동 일한 조건에서 3점 굽힘 시험을 하여 그 강도 값을 나타 내었다. Fig. 6에서와 같이 코팅에 의해 모재를 보호할 수 있는 효과가 있는 것으로 판단되며, 따라서 코팅된 구조 체의 강도 값은 다공성 알루미나 모재의 영향을 크게 받 는 것으로 분석할 수 있다.

본 연구에서 제작한 유리/다공성 알루미나 구조체는 모 재에 기공을 도입하여 경량화시키는 것이 가능할 뿐만 아 니라 코팅층 도입에 의해 동시에 강도의 향상을 가져올 수 있다. 이러한 결과를 보여주는 것이 Fig. 7이다. 그림 에 경량화의 비율과 함께 Fig. 6에서 측정한 강도 평균값 에 대한 향상의 비율을 기공율의 함수로 도시하여 그 가 능성을 나타내었다.

\section{4. 결 론}

본 연구에서는 유리/다공성 알루미나의 코팅구조체를 제조하였으며, 이 때 모재층의 기공율 $(5.2 \sim 47.5 \%)$ 이 구 속된 접촉하중 하에서 표면에 형성되는 균열들의 개시하 중과 진전된 크기에 미치는 영향을 연구하였다. 다공성 알루미나 모재와 두께 $160 \mu \mathrm{m}$ 의 현미경 커버글라스를 에 폭시 접착제로 접합한 후 반경 $3.18 \mathrm{~mm}$ 의 초경 구를 사 용하여 접촉하중 $P=150,250,350 \mathrm{~N}$ 등에서 압흔실험
을 수행하였다.

그 결과 모재의 기공율은 코팅층의 파손에 큰 영향을 미쳐 기공율이 $30 \%$ 이상인 경우 방사성균열에 의한 현 저한 파괴가 일어났으며, 기공율을 $30 \%$ 미만으로 제어할 경우 모재층의 탄성계수가 높을수록 균열의 개시 및 성 장을 억제하는 결과를 보였다. 또 기공율을 적절히 제어 할 경우 원형균열의 개시하중을 증가시켜 균열형성을 억 제할 수 있었다. 이러한 결과는 코팅에 의해 상대적으로 경량이면서도 강도를 향상시킬 수 있는 기계부품을 제조 하는데 기여할 수 있을 것으로 기대된다.

\section{Acknowledgment}

본 논문은 2013년도 국민대학교 교내연구비의 지원금 으로 수행된 연구결과입니다.

\section{REFERENCES}

1. A. A. Tracton, Coatings Technology Handbook; pp. 181 45-7, CRC Tayler \& Francis, New York, 2006.

2. S. C. Tjong and H. Chen, "Nanocrystalline Materials and Coatings," Mater. Sci. Eng. R, 45 [1-2] 1-88 (2004).

3. B. R. Lawn, K. S. Lee, H. Chai, A. Pajares, D. K. Kim, S. Wuttiphan, I. M. Peterson, and X Hu, "Damage-resistant Coatings," Adv. Eng. Mater., 11 745-48 (2000).

4. K. S. Lee, B. K. Jang, and Y. Sakka, "Damage and Wear Resistance of $\mathrm{Al}_{2} \mathrm{O}_{3}$-CNT Nanocomposites Fabricated by Spark Plasma Sintering," J. Ceram. Soc. Jpn., 121 867-72 (2013).

5. J. Wei and L. R. Dharani, "Fracture Mechanics of Laminated Glass Subjected to Blast Loading," Theor. Appl. Fract. Mech., 89 545-52 44 [2] (2005).

6. J. H. Park, E. Lee, T. W. Kim, H. J. Yim, and K. S. Lee, "Fracture Behavior fo Glass/Resin/Glass Sandwich Structures with Different Resin Thicknesses," J. Mech. Sci. Technol., 34 81849-56 (2010).

7. C. Ortiz and M. C. Boyce, "Bioinspired Structural Materials," Science, 319 [5866] 851-6 (2008).

8. B. R. Lawn, S. Bhowmick, M. B. Bush, T. Qasim, E. D. Rekow, and Y. Zhang, "Failure Modes in Ceramic-Based Layer Structures : A Basis for Materials Design of Dental Crowns," J. Am. Ceram. Soc., 90 1671-83 (2007).

9. S. K. Woo, K. S. Lee, I. S. Han, D. W. Seo, and Y. O. Park, "Role of Porosity in Dust Cleaning of Silicon Carbide Ceramic Filters," J. Ceram. Soc. Jpn., 109 [9] 742-47 (2001).

10. K.-J. Lee, J.-W. Park, J.-K. Yang, K.-S. Lee, and Y.-H. Choa, "Synthesis and Optimization of Nano-Porous $\mathrm{La}_{0.6} \mathrm{Sr}_{0.4} \mathrm{Co}$ $\mathrm{O}_{3-\delta}$ on the Oxygen Separation Membrane," Mater. Sci. and Eng. A., 449-451 774-77 (2007).

11. D. H. Lee and K. S. Lee, "Mechanical Behavior of Layered YSZ Thermal Barrier Coatings Using Indentation Test $($ in Korean)," J. Korean Ceram. Soc., 48 [5] 396-403 (2011). 
12. C. M. Herveran, J. Xu, V. K. Sarin, and S. N. Basu, "Simulation of Stresses in TBC-EBC Coating Systems for Ceramic Components in Gas Turbines," Surf. Coat. Technol., 235 [14-15] 354-60 (2013).

13. J. Kimmel, N. Miriyala, J. Price, K. More, P. Tortorelli, H. Eaton, G. Linsey, and E. Sun, "Evaluation of CFCC Liners with EBC after Field Testing in a Gas Turbine," J. Eur. Ceram. Soc., 22 2769-75 (2002).

14. K. S. Lee, K. S. Jang, J. H. Park, T. W. Kim, I. S. han, and S. K. Woo, "Designing the Fiber Volume Ratio in SiC FiberReinforced SiC Ceramic Composites under Hertzian Stress," Mater. Des., 32 [8-9] 4394-401 (2011).

15. B. T. Richards and H. N. G. Wadley, "Plasma Spray Deposition of Tri-layer Environmental Barrier Coatings," J. Eur. Ceram. Soc., 34 [12] 3069-83 (2014).

16. K. Holmberg, H. Ronkainen, A.Laukkanen, and K. Wallin, "Friction and Wear of Coated Surfaces - Scales, Modelling and Simulation of Tribomechanism," Surf. Coat. Technol., 202 [4-7] 1034-49 (2007).

17. R. Ahmad, J.-H. Ha, and I.-H. Song, "Enhancement of the Compressive Strength of Hightly Porous $\mathrm{Al}_{2} \mathrm{O}_{3}$ Foam through
Crack Healing and Improvement of the Surface Condition by Dip-coating," Ceram. Int., 40 [2] 3679-85 (2014).

18. K. S. Lee, S. K. Kim, C. Kim, T. W. Kim, and D. K. Kim "Cracking of Densely Coated Layer Adhesively Bonded to Porous Substrates Under Hertzian Stress," J. Mater. Sci., 42 [21] 9116-20 (2007).

19. B. R. Lawn, "Indentation of Ceramic with Spheres : A Century After Hertz," J. Am. Ceram. Soc., 81 [8] 1977-94 (1998).

20. K. S. Lee, Y. W. Rhee, D. H. Blackburn, and B. R. Lawn, "Cracking of Brittle Coatings Adhesively Bonded to Substrates of Unlike Modulus," J. Mater. Res., 15 [8] 1653-56 (2000).

21. F. W. Zok and C. G. Levi, "Mechanical Properties of PorousMatrix Ceramic Composites," Adv. Eng. Mater., 3 15-23 (2001).

22. K. S. Lee, D. W. Seo, J. H. Yu, and S. K. Woo, "A Study on the Improvement of Strength in NiO-YSZ Porous Anode Material for Solid Oxide Fuel Cell(in Korean)," J. Kor. Ceram. Soc., 40 [3] 241-8 (2003). 